Correction

\title{
Correction: Kelley et al. Use of Multi-Temporal LiDAR to Quantify Fertilization Effects on Stand Volume and Biomass in Late-Rotation Coastal Douglas-Fir Forests. Forests 2021, 12, 517
}

\author{
Jason Kelley ${ }^{1, * \mathbb{C}}$, John A. (Tony) Trofymow ${ }^{2,3}$, Juha M. Metsaranta ${ }^{4}$, Cosmin N. Filipescu ${ }^{5}$ and Christopher Bone ${ }^{1}$ \\ 1 Department of Geography, University of Victoria, Victoria, BC V8P 5C2, Canada; chrisbone@uvic.ca \\ 2 Pacific Forestry Centre, Canadian Forest Service, Natural Resources Canada, 506 West Burnside Road, \\ Victoria, BC V8Z 1M5, Canada; tony.trofymow@canada.ca \\ 3 Department of Biology, University of Victoria, Victoria, BC V8P 5C2, Canada \\ 4 Northern Forestry Center, Canadian Forest Service, Natural Resources Canada, 5320-122 Street, Edmonton, \\ AB T6H 3S5, Canada; juha.metsaranta@canada.ca \\ 5 Canadian Wood Fibre Centre, Canadian Forest Service, Natural Resources Canada, 506 West Burnside Road, \\ Victoria, BC V8Z 1M5, Canada; cosmin.filipescu@canada.ca \\ * Correspondence: jkelley@uvic.ca
}

check for updates

Citation: Kelley, J.; Trofymow, J.A.; Metsaranta, J.M.; Filipescu, C.N.; Bone, C. Correction: Kelley et al. Use of Multi-Temporal LiDAR to Quantify Fertilization Effects on Stand Volume and Biomass in Late-Rotation Coastal Douglas-Fir Forests. Forests 2021, 12, 517. Forests 2021, 12, 1363. https:// doi.org/10.3390/f12101363

Received: 30 September 2021

Accepted: 4 October 2021

Published: 8 October 2021

Publisher's Note: MDPI stays neutral with regard to jurisdictional claims in published maps and institutional affiliations.

Copyright: () 2021 by the authors. Licensee MDPI, Basel, Switzerland. This article is an open access article distributed under the terms and conditions of the Creative Commons Attribution (CC BY) license (https:// creativecommons.org/licenses/by/ $4.0 /)$.
The authors wish to make the following corrections to their paper [1]. We realized that one of our earlier analyses had used a date range off by one year. These values have been adjusted to match the years described in the text and other analyses. Thus, in the corrected version after publication:

1. On page 9, the value "(242 SE 8)" correctly reads "(243 SE 8)".

2. On page 9, the value "(269 SE 10)" correctly reads "(270 SE 10)"

3. On page 9, the value " $(p=0.035)$ " correctly reads " $(p=0.023)$ "

4. On page 9, the value " $(p=0.122)$ " correctly reads " $(p=0.173)$ "

5. On page 9, the value " $(p=0.002)$ " correctly reads " $(p=0.0002)$ "

6. On page 9, the value "(308 SE 9)" correctly reads "(326 SE 6)"

7. On page 9, the value "(266 SE 10)" correctly reads "(271 SE 11)"

8. On page 9 the values " $16 \%$ " correctly reads " $20 \%$ "

9. On page 14-Table 5-Pre-Treat column Row 2, the value " $-7 \%$ " correctly reads "- $4 \%$ "

10. On page 14-Table 5-Post-Treat column Row 2, the value " $-2 \%$ " correctly reads " $0.4 \%$ "

11. On page 14-Table 5-Post-Treat column Row 7, the value " $16 \%$ " correctly reads " $20 \%$ "

Additionally, we noticed that in Table 5 the formula in the caption was missing a " -1 " term and thus the corrected version now reads $(($ Fertilized/Control $)-1) \times 100)$. The authors would like to apologize for any inconvenience caused to the readers by these changes and maintain that the scientific conclusions have been unaffected.

\section{Reference}

1. Kelley, J.; Trofymow, J.A.; Metsaranta, J.M.; Filipescu, C.N.; Bone, C. Use of Multi-Temporal LiDAR to Quantify Fertilization Effects on Stand Volume and Biomass in Late-Rotation Coastal Douglas-Fir Forests. Forests 2021, 12, 517. [CrossRef] 